\title{
THE USE OF DISCOVERY IN UNITED STATES DISTRICT COURTS *
}

\author{
BY WILLIAM H. SPECK $†$
}

Fifteen years ago supporters of the new Federal Rules of Civil Procedure incorporated in Rules 26-37 the most liberal provisions for the disclosure of information concerning lawsuits hitherto known. ${ }^{1}$ They allowed great freedom in discovery, first to fit discovery for a part, along with pleadings and pretrial conferences, in giving notice of contentions and framing issues; second to expedite the administration of justice by making lawyers aware before trial of the strengths and weaknesses of their own and of their opponents' cases so that uncontested issues would be eliminated, settlements facilitated, and trial evidence better organized; and third to make information and evidence more equally available to all parties so that substantive legal rights would not fail for inaccessibility of proof. Discovery was to minimize the so-called "sporting theory of justice" by making the outcome of litigation depend less upon both the availability of evidence and the skillful exploitation of trial surprise.

Today, after thirteen years of experience under liberal discovery rules, complaints are heard. It is said: (1) That discovery is expensive and time consuming out of proportion to benefits; that depositions last weeks, interrogatories and admissions cover thousands of items, and motions to produce call for tons of documents. (2) That discovery is used to pry into private affairs not relevant and material to the litigation. (3) That dilatory discovery motions take up the judges' time and delay disposition. (4) That expensive, dilatory, and embarrassing discovery is deliberately used to harrass the other side into a favorable settlement. (5) That attorneys race to be first with discovery to tie up the other side and saddle it with expense, defendants usually having an unwarranted priority. (6) That, in practice, relief is unobtainable from judges because at the discovery stage they cannot investigate either the issues or the evidence thoroughly enough to rule effectively; judges tend to

*This article is based on information gathered by the Administrative Office of the United States Courts in an investigation of the use of discovery in United States courts, but the evaluations and conclusions from the data presented are not necessarily those of the Office.

$\dagger$ Attorney, Division of Procedural Studies and Statistics, Administrative Office of the United States Courts.

1. Sunderland, Scope and Method of Discovery before Trial, 42 YALE L.J. 863 (1933); Millar, The Mechanism of Fact-Discovery: A Study in Comparative Civil Procedure, 32 ILI. L. Rev. 261, 424 (1937); Pike \& Willis, The New Federal Deposition-Discovery Procedure, 38 Cos. L. REv. 1179, 1436 (1938); Sunderland, Discovery before Trial under the New Federal Rules, 15 TENN. L. REv. 737 (1939); Holtzoff, Instruments of Discovery inder Federal Rules of Civil Procedure, 41 Micr. L. Rev. 205 (1942); DyeR-Smitr, Federal Examinations before Trial (1939). 
say, "answer the questions and don't bother me with these details." (7) That non-reviewable rulings on discovery are not uniform among courts, or among different judges on the same court; that even the same judge at different times fails to give consistent rulings; so that wrangling over discovery is encouraged. (8) That suits are tried by deposition or other discovered materials without the prophylactic influence of observing the witness under cross-examination. (9) That perjury is promoted both by furnishing the information with which an unscrupulous party can fabricate a convincing story and by reducing the opportunity to surprise the perjurer with contradictory evidence. And (10) that lawyers use discovery to take advantage of the trial preparations of the other side so that careful investigation is unrewarded and intraorganization reports cannot be frank. These allegations appeared in testimony before Congress ${ }^{2}$ and were documented in articles and comment. ${ }^{3}$

This disquieting contrast between glowing hopes and alleged sordid realities prompted the Administrative Office of the United States Courts at the suggestion of Judge Charles E. Clark of the United States Court of Appeals for the Second Circuit to investigate so far as limited time and resources permitted the use of discovery in federal district courts. This investigation has covered to varying extents the District of Columbia, Maryland, Alexandria in the Eastern District of Virginia, the Eastern District of Pennsylvania (Philadelphia), the Southern District of New York, and the Eastern Division of the Northern District of Illinois (Chicago). The sources of information were: (1) An examination of the dockets of cases filed in a fiscal year, tusually 1948, for those showing some sign of discovery activity. See Tables 1 and 2, pages 1135 and 1137 (2) A search of the files for further information on a limited number of cases for each type of discovery. 4 See Tables 3-6, pages $1139,1145,1147$, and 1149. (3) Interviews with twenty lawyers active in

2. See testimony of Walton Hamilton, Hearings before Subcommittee on Study of Monopoly Power of the Committee of the Judiciary, House of Representatives, S1st Cong., 1st Sess. 285-99 (1949).

3. Caskey \& Young, Some Further Comments upon Rule 33 of the Federal Rules of Civil Procedure, 33 VA. L. Rev. 125 (1947); Tactical Use and Abuse of Depositions under the Federal Rules, 59 Y ALE L.J. 117 (1949); Dike, A Step Backward in the Federal Contrts: Are We Returning to Trial by Deposition?, 37 A.B.A.J 17 (Jan. 1951); Whitney, The Trial of an Anti-Trust Case, 5 The Record of the Association of tue Bar of New YORK 449, 464 (1950); Dawson, Examinations before Trial in the State Courts and Depositions in the Federal Courts, 6 id. at 12 (1951); Yudkin, Some Refinements it Federal Discovery Procedure, 11 FED. B.J. 289 (1951). Compare generally favorable evaluations in Koch, Deposttrons and Discovery under tere Federal Rules (Practicing Law Institute, Trial Practice Series, No. 8, 1946) ; Freedman, Discovery as an Instrument of Justice, 22 Texr. L.Q. 174 (1948); Cushman, Depositions in Practice, 3 Mranr L.Q. 378 (1949).

4. These cases were chosen at random by beginning with the first docket number in which the docket showed use of discovery and continuing so far as time permitted until 100 or more items of each type of discovery had been found or the cases exhausted. The selection included the following: 
the federal courts for both plaintiffs and defendants and in both business and tort litigation concerning patterns of use and abuse of discovery which they had observed in their practice. (4) Correlation of the above information with data on the cases in each district already available in the Administrative Office. ${ }^{5}$

An investigation largely limited to discovery in court records is necessarily incomplete because much discovery is carried on formally without filing papers or informally without any papers. But further investigation outside the records would be extremely time consuming in proportion to the data obtainable and would raise questions of how much should be included. For example, should such a study count the furnishing of the names of eye witnesses over the telephone when both attorneys knew the information could be required by interrogatory? And how should such a study count the furnishing of the statements of witnesses to forestall taking their depositions? Except as noted, information on discovery based on the court records is believed to be representative of all discovery.

\section{USE OF Discovery}

The federal discovery rules are popular; the dockets show their use in over $25 \%$ of the cases filed. This percentage figure should be appraised with due allowance that many cases filed are never seriously pressed and that it does not include a large amount of both discovery carried on without filing papers and information furnished voluntarily under pressure of the rules. Discovery was most popular in Philadelphia where $37 \%$ of the cases disclosed its use. See Table 1, page 1135. It was least popular in the District of Columbia, probably because many local jurisdiction cases including divorce do not require discovery investigation. Part of the difference between districts may be attributed to the types of cases filed: for example, while discovery is seldom employed in the large number of habeas corpus cases in Chicago it is used

\begin{tabular}{|c|c|c|c|c|}
\hline N. I. Y. So. $1948 . \ldots \ldots$. & $\begin{array}{l}\text { Depositions } \\
\cdot \quad 101\end{array}$ & $\begin{array}{c}\text { Interrogatories } \\
167\end{array}$ & $\begin{array}{c}\text { Production or } \\
\text { Inspection } \\
76\end{array}$ & $\begin{array}{c}\text { Admissions } \\
34\end{array}$ \\
\hline Рa. E. $1948, \ldots \ldots \ldots \ldots$ & . $108^{*}$ & 113 & $32^{*}$ & $73^{*}$ \\
\hline Md. $1947-48 \ldots \ldots \ldots \ldots$ & $69 *$ & $93 *$ & $35 *$ & $51 *$ \\
\hline Va. E. $1947-50 . \ldots \ldots$. & $27 *$ & $13^{*}$ & $8^{*}$ & $27 *$ \\
\hline IIl. N. 1948. & $86^{*}$ & 131 & $85^{*}$ & $103^{*}$ \\
\hline Total. & 391 & 517 & 236 & 288 \\
\hline
\end{tabular}

For the starred $\left(^{*}\right)$ items the selection included all of that type of discovery found in the files for the years and districts indicated.

5. Earlier studies of the use of discovery including some statistics are RAGLAND, DisCovery before Trial (1932); Stockman, Some Statistical Observations on the Operation of Discovery and Related Provisions of the Federal Rules of Civit Procedure (typewritten study in the Administrative Office of the United States Courts, 1942); Tactical Use and Abuse of Depositions under the Federal Rules, 59 YaLE L.J. 117 (1949). The statistical findings of this study are corroborated in most respects by those of Mr. Stockman. 


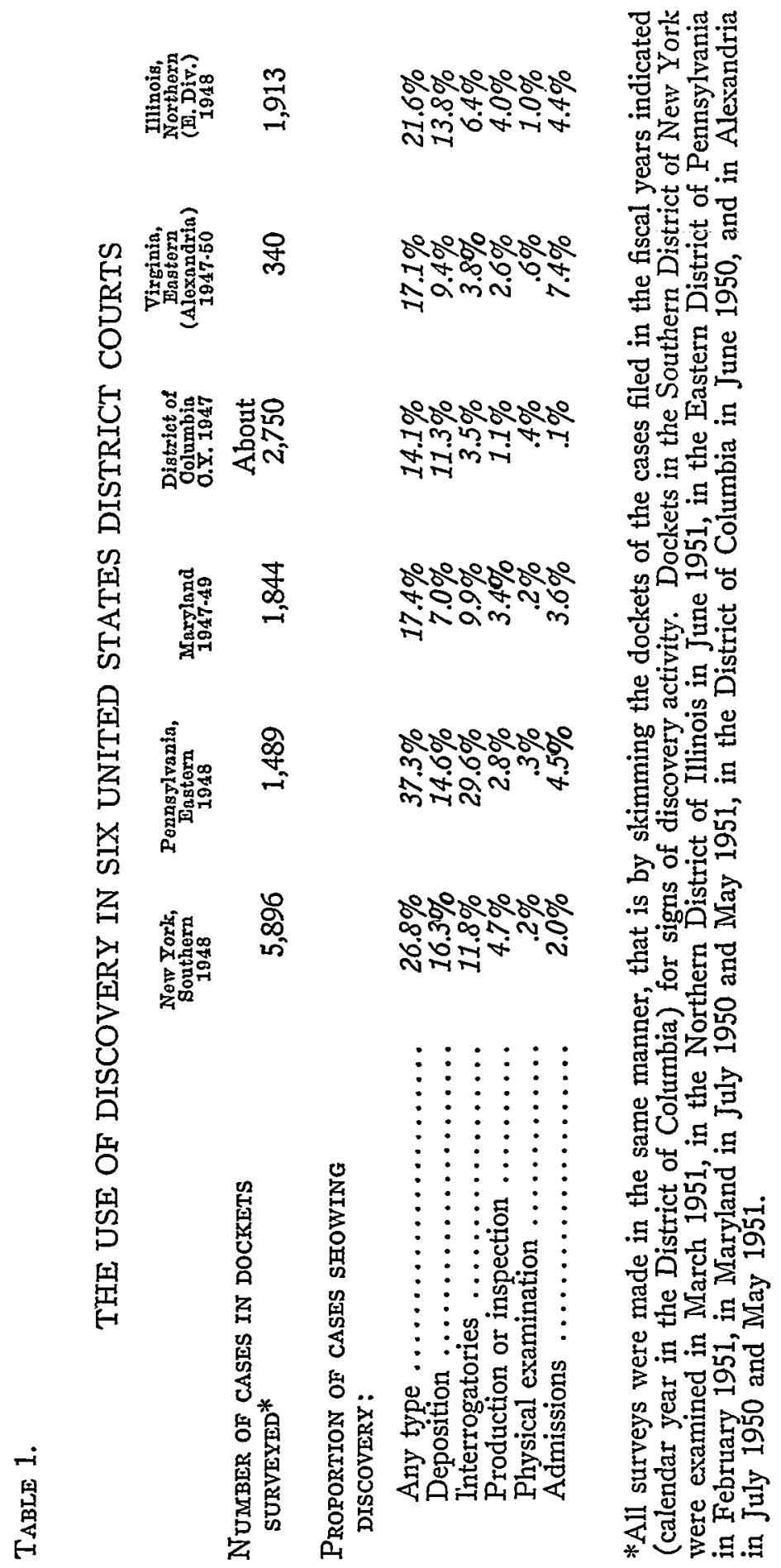


extensively in the large number of Jones Act cases in Philadelphia. Part seems to be attributable to the liberality of the judges toward discovery: for example, the extensive use of interrogatories and other discovery devices in Philadelphia probably results from both the use of interrogatories to get copies of statements and that court's coolness toward restrictions on inquiry. ${ }^{6}$

Among discovery devices the deposition is most popular. It was found in $14 \%$ of the cases, but was surprisingly close pressed by interrogatories in $13 \%$ of the cases. Interrogatories actually were more popular than depositions in Philadelphia and Maryland. Motions to produce were found in only $4 \%$ of the cases, requests for admissions in only $3 \%$, and motions for physical examinations scarcely appeared at all. The use of all these devices was certainly greater than the dockets showed; for many depositions are taken by agreement of the parties without filing either notices or transcripts. In addition, much information and many documents requestable by interrogatories or producible on motion are furnished voluntarily, and both physical examinations and medical reports are usually made without resort to the courts.

Use of discovery was not uniform in the various types of cases. See Table 2 page 1137. Among United States Plaintiff cases, discovery was used comparatively little. It was used in only $11 \%$ of these cases, and then chiefly in OPA-Rent Control cases (23\%) with many admissions, and to a lesser extent in both contract suits and the miscellaneous "other" category. Among United States Defendant cases, discovery was resorted to in $16 \%$ of the cases. But this more extensive use was largely confined to Tort Claims Act suits (30\%) and the "other" category, largely tort suits in Admiralty.

The use of discovery in Tort Claims Act suits is only illustrative of its extensive utilization in all tort litigation: whether under Federal Question jurisdiction in Federal Employers' Liability Act, (FELA), (44\%) or Jones Act $(43 \%)$ suits or under Diversity jurisdiction in personal injury motor vehicle $(34 \%)$ or other $(48 \%)$ suits. The greatest use of discovery in any district in any one type of suit was in $72 \%$ of the Jones Act suits filed at Philadelphia. Considering that much discovery does not appear in the records and that many suits are quickly dismissed or never seriously pushed, it is believed that discovery is employed in virtually every seriously contested tort case in Philadelphia and New York and in most of such suits in Maryland. Virginia, and Chicago.

Among Federal Question cases, discovery was used in a third of the cases. It was most frequently employed in tort suits, but use was also extensive in Federal specialties : copyright (41\%), patent, (26\%) and Fair Labor Standards Act, (FLSA), (42\%). In habeas corpus cases, where discovery ought

6. Hickman v. Taylor, 4 F.R.D. 479 (E.D. Pa. 1945), rev'd, 153 F.2d 212 (3d Cir. 1945) and 329 U.S. 495 (1947); De Bruce v. Pennsylvania R. Co., 6 F.R.D. 403 (E.D. Pa. 1947), overruled in Alltmont v. United States, 177 F.2d 971 (3d Cir. 1950) ; Nedimyer v. Pennsylvania R. Co., 6 F.R.D. 21 (E.D. Pa. 1946) ; Love v. Metropolitan Life Ins. Co., 8 F.R.D. 583 (E.D. Pa. 1948) ; Brauner v. United States, 10 F.R.D. 468 (E.D. Pa. 1950); Mandel v. United States, 93 F. Supp. 692 (E.D. Pa. 1950). 
TABLE 2. USE OF DISCOVERY BY TYPE OF CASE IN FIVE UNITED STATES DISTRICT COURTS*

Nature of Suit

Total Civil Cases

U. S. Plaintiff Total

Land Condemnation

OPA-Rent Control

Fair Labor Stand. Act

Other Enforcement

Food and Drug Act

Liquor Laws

Other forfeitures

Negotiable Instrument

Other contracts

Other U. S. Plaintiff

U. S. Defendant Total

Habeas Corpus

Tort Claims Act

Tax Suits

Other U. S. Defendant

Federal Question Total

Copyright

FELA

FLSA

Habeas Corpus

Jones Act

Miller Act

Patent

Other Federal Question

Drversity Total

Insurance

Other contract

Real Property

Personal injury (auto)

Personal injury (other)

Other Diversity

$\begin{array}{rr}\begin{array}{c}\text { Cases } \\ \text { Commenced }\end{array} & \begin{array}{c}\text { Any } \\ \text { Type }\end{array} \\ 11,482 & 2,93 \\ 1,931 & 211 \\ 29 & 2 \\ 653 & 152 \\ 71 & 5 \\ 177 & 13 \\ 366 & 3 \\ 11 & - \\ 111 & 3 \\ 343 & 5 \\ 71 & 10 \\ 99 & 18\end{array}$

1,589

179

165

102

1,143

3,504

90

421

408

308

1,332

15

159

771

2,486

162

757

51

663

579

274

1,972
36.5

246

50

8

188

1,149

37

186

171

1

573

1

42

138

960

51

290

11

223

277

108

\section{Cases Showing Use Of Discovery}

\begin{tabular}{|c|c|c|c|c|}
\hline $\begin{array}{c}\text { Deposi. } \\
\text { tions }\end{array}$ & $\begin{array}{c}\text { Interroga- } \\
\text { tories }\end{array}$ & $\begin{array}{l}\text { Prod. } \\
\text { Insp. }\end{array}$ & $\begin{array}{c}\text { Phy. } \\
\text { Exsm. }\end{array}$ & $\underset{\text { sions }}{\text { Admis- }}$ \\
\hline 1,605 & 1,454 & 465 & 40 & 358 \\
\hline 49 & 67 & 18 & - & 148 \\
\hline 1 & 1 & - & - & - \\
\hline 21 & 45 & 6 & 一 & 130 \\
\hline 3 & 3 & - & - & 1 \\
\hline 6 & 5 & 1 & - & 7 \\
\hline - & 1 & 1 & - & 1 \\
\hline - & - & - & - & - \\
\hline 2 & 1 & - & - & 一 \\
\hline 1 & - & 1 & - & 3 \\
\hline 5 & 2 & 4 & - & 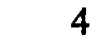 \\
\hline 10 & 9 & 5 & - & 2 \\
\hline 102 & 149 & 37 & - & 20 \\
\hline- & - & - & - & - \\
\hline 38 & 12 & 9 & - & 3 \\
\hline 5 & - & - & - & 4 \\
\hline 59 & 137 & 28 & 一 & 13 \\
\hline 678 & 615 & 196 & 16 & 90 \\
\hline 31 & 8 & 7 & - & 6 \\
\hline 104 & 111 & 14 & 1 & 19 \\
\hline 44 & 133 & 24 & - & 6 \\
\hline 1 & - & 1 & - & 1 \\
\hline 376 & 293 & 123 & 15 & 22 \\
\hline- & - & 一 & - & 1 \\
\hline 29 & 27 & 7 & - & 6 \\
\hline 93 & 43 & 20 & - & 29 \\
\hline 703 & 298 & 146 & 24 & 86 \\
\hline 34 & 13 & 10 & - & 12 \\
\hline 241 & 70 & 58 & - & 35 \\
\hline 9 & 1 & 1 & - & 3 \\
\hline 144 & 85 & 17 & 16 & $y$ \\
\hline 205 & 95 & 32 & 8 & 22 \\
\hline 70 & 34 & 28 & 一 & 5 \\
\hline 73 & 325 & 68 & - & 14 \\
\hline
\end{tabular}

73

* See footnote to Table 1 for the sources of this table and the number of cases from each district. The District of Columbia was omitted from this and subsequent tables because of its special jurisdiction and different type of judicial business. 
to prove helpful, it is almost never used $(.3 \%)$ apparently because indigent prisoners lack means to employ the devices. Among Diversity cases discovery use was the highest for any type of jurisdiction (39\%). It was again most extensively used in tort cases. In personal injury suits not involving a motor vehicle, for example, $48 \%$ showed some employment of discovery. But use was also heavy in business cases, especially contract (38\%) and "other" Diversity (39\%). Among Admiralty cases, use of discovery except for interrogatories use was below average (18\%).

We turn now from the use of discovery in various types of suits to the five discovery devices themselves.

\section{Depositions}

Deposition, the most popular discovery device, ${ }^{7}$ was found in $14 \%$ of the cases filed. Its popularity included not only tort cases under the Tort Claims Act $(23 \%)$, FELA (25\%), and Jones Act (28\%), and in Diversity personal injury motor vehicle $(22 \%)$ and other $(35 \%)$, but also business cases such as copyright $(34 \%)$, patent $(18 \%)$, insurance $(21 \%)$, contract $(32 \%)$, and "other" Diversity $(26 \%)$. This popularity extended not only to the number of cases in which the deposition was employed but also to the degree of utilization in these cases. Thousands of pages of depositions were taken in the New York Investment Bankers anti-trust case; about a hundred depositions appear to have been taken in both the New York Ferguson v. Ford Motor Co. (Civ. 44-482) and Kaiser-Frazer v. Otis (Civ. 45-564) cases; and a defendant proposed to take 307 depositions in a Chicago Taft-Hartley case. Such extensive use has been criticized. ${ }^{8}$

But the deposition is also the most expensive and burdensome discovery device. It requires the presence of witness, reporter, and lawyers; necessitates payment of witness, reporter, and transcription fees; and sometimes involves travel expenses for lawyers and witnesses.

The deposition is most often a weapon of defendants but not overwhelmingly so. See Table 3 page 1139. This Table, based on depositions filed, actually shows more depositions taken by plaintiffs than by defendants. Plaintiffs seem to file depositions more often than do defendants for use in evidence. Counts in New York and Chicago of notices to take depositions as well as depositions filed revealed greater use by defendants. Many large corporations which are frequent defendants in tort suits-railroad, shipping, taxicab, and insurance companies-make a general practice of taking the deposition of the plaintiff as soon as they file their answer. And they often take the depositions of all important witnesses from whom they do not have signed statements.

7. The deposition probably received its greatest publicity when Whittaker Chambers, at a deposition in a civil libel suit, produced the secret State Department papers that convicted Alger Hiss. Hiss v. Chambers, 8 F.R.D. 480 (D. Md. 1948).

S. Whitney, supra note 3, at 467; United States v. Morgan, 10 F.R.D. 240, 243 (1950). 


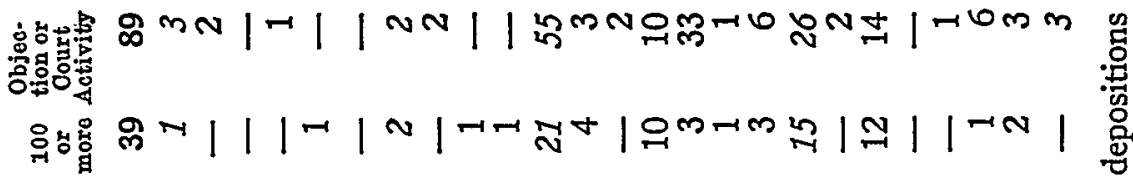

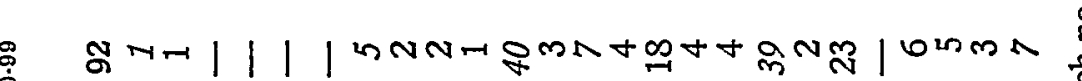

官

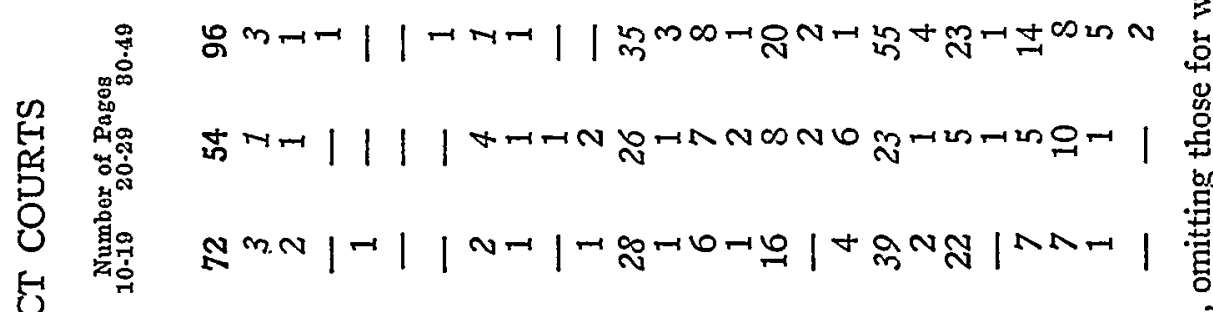

(4)

(1)

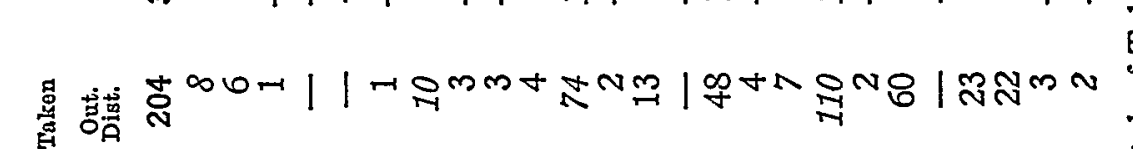

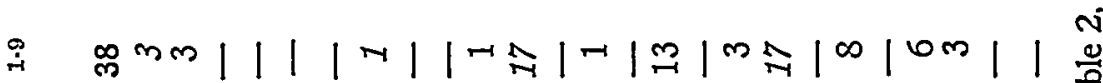

\&

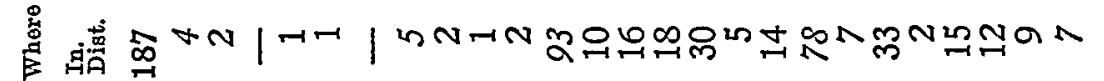

节.

외

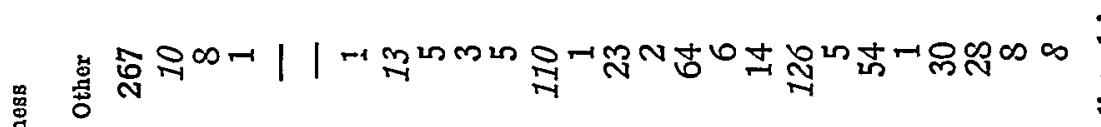

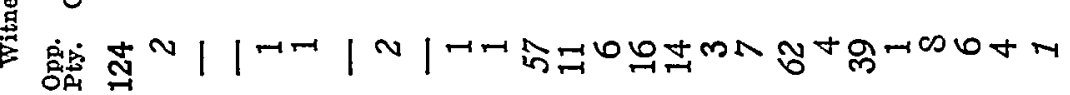

红

mคั

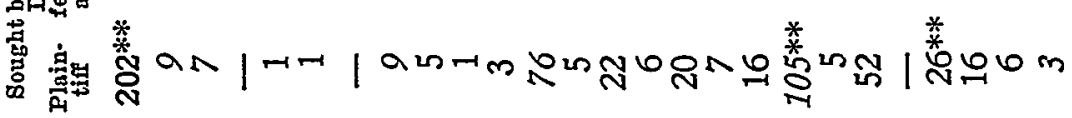

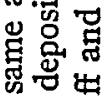

兽造总

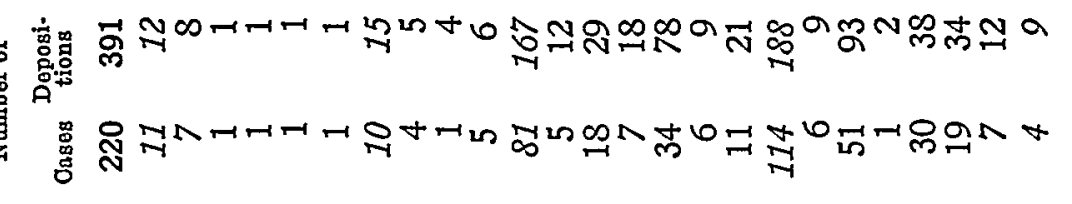

娄

息

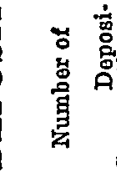

总㤩

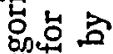

总实言

焗䓀

范葍

氙哥

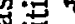

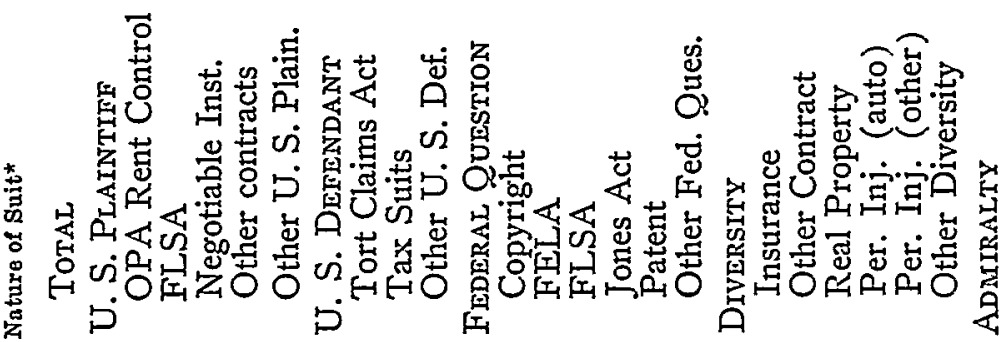

㟧 
The opposite party or an agent entitled to speak for him was a witness in almost one third of the depositions. This proportion is probably too high because of the liberal provisions for the use of depositions of the opposite party in evidence under Rule 26(d)(2). The opposite party appeared as deposition witness especially often in copyright, FLSA, and contract cases. This is to be expected because few other than party witnesses to the transactions are involved in such cases.

Depositions are probably taken of witnesses residing outside the district in only about one quarter of the cases. Here again, the data is somewhat misleading; the depositions found in the files were most often taken outside the district because such depositions are more likely to be admissible in evidence and therefore filed. And the other side may not be present at distant deposition takings to waive filing. But notices to take depositions give more representative data. Counts including notices to take depositions as well as depositions filed showed that only one ninth of the New York depositions, only one fifth of the Philadelphia depositions, and less than one third of the Chicago depositions were taken outside the district. The expense of outside depositions can be minimized by taking them on written interrogatories, but only 43 of 204 outside depositions were so taken. Travel and attorney expense for outside depositions can either seriously burden a poor party or handicap him by obliging him to forego cross-examination. But the courts in Philadelphia and New York have ameliorated this problem for poor parties by requiring the party proposing an outside deposition to take it on written interrogatories or to pay the expense of attendance for the other party's counsel. 9 Occasionally, in Philadelphia, judges have also authorized cross-examination by written interrogatories following an opportunity to read the transcript of the oral direct examination.

Despite the overwhelming use of depositions in the big cases mentioned, typical use is quite modest. The average number of depositions per case was less than two, and the median length of the depositions was only 35 pages. ${ }^{10}$

9. Gibson v. International Freighting Corp., 8 F.R.D. 487 (E.D. Pa. 1947), aff'd, 173 F. 2d 591 (3d Cir. 1949); cf. Jones v. Pennsylvania Greyhound Lines, Inc., 10 F.R.D. 153 (E.D. Pa. 1950); see Fred Benioff Co. v. McCulloch, 133 F.2d 900 (9th Cir. 1943). Civil Rule 12, United States District Court for the Southern District of New York, expressly authorizes the court to require pre-payment of expenses for depositions more than 150 miles from New York; Fairwater Transp. Co. v. Chris-Craft Corp., 1 F.R.D. 509 (S.D. N.Y. 1940) ; Houghton Mifflin Co. v. Stackpole Sons, 1 F.R.D. 506 (S.D. N.Y. 1940) ; Moore v. George A. Hormel, 2 F.R.D. 340 (S.D. N.Y. 1942); Stevens v. Minder Const. Corp., 3 F.R.D. 498 (S.D. N.Y. 1943) ; Moore v. George A. Hormel \& Co., 4 F.R.D. 15 (S.D. N.Y. 1942) ; Boiczuk v. Baltimore \& Ohio R. Co., 5 F.R.D. 18 (S.D. N.Y. 1944).

10. A deposition is here taken as whatever the reporter paged continuously and bound together as one document, so that a deposition may include more than one witness. In the comparatively few depositions containing testimony of more than one witness, the witnesses were always examined consecutively at the same place. Therefore, treating their combined testimony as one deposition seems a more accurate unit for measuring 
Fewer than one tenth of the depositions were 100 or more pages long. The longest, 525 pages, was used in a New York contract case. The average number of pages of depositions per case in cases using depositions was only 44 pages for FELA cases, 80 pages for Jones Act cases, 106 pages for contract cases, 39 pages for personal injury motor vehicles cases, and 61 pages for other personal injury cases. Translating these lengths into time and transcription cost at the rate of 30 pages per hour and 75 cents per page for original copy, the median deposition took slightly over one hour and cost about $\$ 25$ for transcription plus the expense of travel, witnesses, and counsel. Standard counsel fee for taking a deposition seems to be $\$ 50$. The longer depositions seem to be more common in copyright, FLSA, contract, and the miscellaneous "other" Federal Question and Diversity cases.

Objections or other applications for court relief appeared in about one fourth of the depositions, most often in Jones Act, FLSA, contract, and certain personal injury cases. This high proportion is probably misleading because depositions which become controversial are more likely to find their way into the files than those which are taken in harmony.

Lawyers generally stated that they seldom used depositions as evidence because they preferred to have the trier of facts hear their examination or cross-examination. However, a search of the trial clerk's minutes in the Southern District of New York for July through December 1950 showed use of 133 depositions in 45 out of the 150 trials held during this period (or more accurately in 45 out of 103 trials excluding 47 short OPA-Rent trials). Use in evidence was most extensive in Jones Act and Admiralty trials. A similar search in Maryland for the period July 1950 through April 1951 revealed the use of 55 depositions in 22 out of 77 trials, principally in patent, contract, and Diversity personal injury cases. The appendices to briefs in the United States Court of Appeals for the Third Circuit containing crucial evidence disclosed reliance on depositions in perhaps one fifth of the cases. Thus depositions are probably employed in only about one third of the trials. And the limitations of their use under Rule 26(d)(3) to situations where the witness cannot be produced in court is emphasized by the greater degree of use in New York Admiralty trials where witnesses are often scattered throughout the world.

Apart from the very extensive use by defendants to take the deposition of the plaintiff immediately after answer-often by notice attached to the answer-no general pattern in the use of depositions was observed. In a Jones Act suit the plaintiff may be questioned about the accident, his injuries, and his employment before and after the injury; the purser, usually in charge of first aid, testifies to first symptoms and treatment; the master describes

the burden upon the parties and attorneys than the perhaps technically more accurate breaking up of the document among the witnesses. If a deposition were defined as the testimony of one witness, the median length of depositions would be somewhat shorter and the average number per case somewnat larger. 
the operation in which the accident occurred and what was done for the injured man; doctors describe treatments and give opinions on disability; etc. In business cases depositions typically involve questioning witnesses at length concerning commercial transactions and cross-examining them on numerous papers and records.

\section{Interrogatories}

One of the biggest surprises is the usefulness, popularity, and versatility of the old written interrogatory to the parties. Its chief advantage is cheapness and convenience. Interrogatories were found in $13 \%$ of the cases, in almost as many cases as depositions. In fact, they were more popular than depositions in Philadelphia and Maryland. They were used most often in Fair Labor Standards Act (33\%), Federal Employers Liability Act (26\%), and Jones Act $(22 \%)$ cases and to a lesser extent in patent, Admiralty, and Diversity personal injury cases.

Interrogatories were used most commonly as "ground breakers" in tort cases in order to get the names both of eye witnesses and other employees, details of equipment, reports, etc. In most extreme form the plaintiff in a Philadelphia FELA or Jones Act case might call upon the defendant to "state all the facts" he knows about the case and to attach copies of all reports. ${ }^{11}$ And defendant would answer by saying he had no information except as contained in attached reports or statements. These preliminary interrogatories, varying from one to thirty or more questions, sought to elicit for the plaintiff all that the defendant knew about the accident and to furnish leads for more detailed investigation by deposition or motion to produce. Similarly New York retail stores, defendant in personal injury suits, filed interrogatories asking for the date of the accident, where it occurred, particular respects in which defendant is claimed to have been negligent, injuries received, length of confinement in the hospital and time away from work, extent and permanence of present incapacity, doctors' bills, and other special damages. Such an interrogatory amounts to a request for a bill of particulars. In addition, when a defendant interposes frivolous denials, detailed interrogatories can dispose of uncontested issues. For example, if a FELA case defendant denies everything except employment of the plaintiff, questions concerning the track

11. E.g. in No. 9187 in the Eastern District of Pennsylvania the interrogatory read:

"State all of the facts relating to the defense of the plaintiff's claim for injury and disability, which is the subject matter of this litigation as to which you, your attorney, or any other representatives have information, including all of the facts relating to the injuries, disability and treatments. Attach to your answer to this Interrogatory copies of all statements, documents, papers and reports, not privileged, having any relation to or containing any facts relating to the subject matter of this litigation."

Since Alltmont v. U. S., 177 F.2d 971 (3d Cir. 1950), copies of statements cannot be demanded by interrogatory. These "state all the facts" interrogatories were designed to avoid dozens of separate interrogatories covering the same ground that are more burdensome to prepare and answer. 
on which plaintiff was working and the number, origin, and destination of trains using that track often lead defendant to admit plaintiff was working in interstate commerce.

Plaintiffs in private anti-trust cases have used interrogatories to get information that would neither be known by any witness nor be available in any document. For example, they have asked defendant moving picture distributors for titles of all pictures shown at theaters serviced over a period of years, for box office receipts and film rentals, for seating capacity and other theater appointments that led to the preference of one movie house over another, for names of persons conducting picture negotiations, etc. Some defendants have objected to the labor of compiling this information; but plaintiffs' attorneys have pointed out that if they asked for the books and compiled the information themselves, defendants would be obliged to go to as much trouble and expense to check the compilation. Motions to produce and depositions are then used to follow up on data disclosed by the interrogatories, and requests for admissions are used to tie together all information obtained. Though objections to interrogatories calling for research and investigation are frequently raised, such interrogatories are now often permitted. ${ }^{12}$

In Admiralty, interrogatories are the primary method of inquiry because of custom, cheapness, convenience, and the doubtful legal status of depositions. ${ }^{13}$

The only general pattern of the abuse of discovery appeared in the use of interrogatories in FLSA cases involving portal-to-portal and overtime-onovertime issues. These cases were typically brought by hundreds or thousands of individual plaintiffs against one or more stevedoring or shipping firms. The defendants almost invariably served interrogatories, with their answers or soon thereafter, calling upon the plaintiffs' attorneys to give the name, address, social security number, company number, periods of employment, and customs of employment as to each plaintiff or each plaintiff claimed to have been employed by the particular defendant. Theoretically plaintiffs should be able to make their claims specifically in terms of hours worked on particular days, but these plaintiffs were uneducated workmen whose employment had shifted frequently-in the case of stevedores, perhaps from day to day-and who had kept no records and could not possibly remember their work hours over the several years in litigation. The defendants, who could obtain this information from their own records, could not have seriously expected the plaintiffs to furnish it. Thus such interrogatories were probably filed to harrass the plaintiffs and gain advantage in relief under Rule 37 . In certain New York cases the plaintiffs retaliated by asking for 33 items of information relating to hours and shifts worked, cargo handled, customers

12. Moore's Federal Practice $\$ 33.20$ (1950); cf. United States v. United Shoe Machinery Corp., 76 F. Supp. 315, 317 (D. Mass. 1948) (judge suggested research might be made available as quid pro quo for limiting production).

13. Compare Mercado v. U. S., 184 F.2d 24 (2d Cir. 1950) with Dowling v. Isthmian S.S. Co., 184 F.2d 758 (3d Cir. 1950). 
served, etc. for each of 5000 plaintiffs. Here the burden upon defendants of answering, if their records even contained the information, would be tremendous. These questions should have been handled by thorough investigation of a few selected employees, the results as to these to govern the others.

The interrogatory is primarily a plaintiff's weapon, except in FLSA and contract suits. See Table 4 page 1145. Note that the over-all number of interrogatories presented by defendants is increased in this study by the unusual number of FLSA cases. The number of items was generally quite small-the median was about $20^{14}$-and the number would have been even smaller if it had not been for the heavy representation of FLSA cases in which a few questions applied to each of a large number of plaintiffs. Apart from FLSA cases large numbers of questions were asked only in patent, miscellaneous "other" Federal Question cases and Diversity contract and personal injury cases other than motor vehicle. Only slightly over half of the interrogatories appear to have been answered; in the remainder answers were made informally, answering was excused on objection, or the questions were abandoned. Out of 276 interrogatories answered only 72 answers were made within the 15 days allowed by Rule 33. Interrogatories are much more numerous and require more labor to answer than the rules contemplated, and in any large organization even simple questions may require longer than 15 days to answer.

Interrogatories seem to generate an unwarrantedly large number of objections and applications to the court. Objections or some other form of application to the court or action by the court appeared in well over one third of the interrogatories, particularly in FELA, FLSA, Jones Act, contract, and personal injury cases other than motor vehicle. The large number of objections to interrogatories is confirmed by an examination of the motion calendars: one fifth of the matters on the argument lists at Philadelphia during the calendar year 1950 and $16 \%$ of the matters on the motion calandars in New York during January and February 1951 dealt with interrogatories. The reasons for the number of objections to interrogatories may be surmised. Since the questions are set forth, the scope of inquiry is apparent and objections for relevance are encouraged; some fear that answering will waive objections. ${ }^{15}$ Furthermore the short time limits to object and answer seem to encourage hasty objections, in some instances simply to gain time.

14. Compare Judge Chesnut's frequently quoted admonition in Coca Cola Co. v. Dixie-Cola Laboratories, 30 F. Supp. 275 (D. Md. 1939), that interrogatories be limited to the few important facts and should rarely number more than 15 or 20; Caskey \& Young, Some Linitations upon Rule 33 of the Federal Rules of Cizil Procedure, 28 VA. L. Rev. 348 (1942) ; Caskey \& Young, supra note 3.

15. National Transformer Corp. v. France Mfg. Co., 9 F.R.D. 606, 607 (N.D. Ohio 1949). 


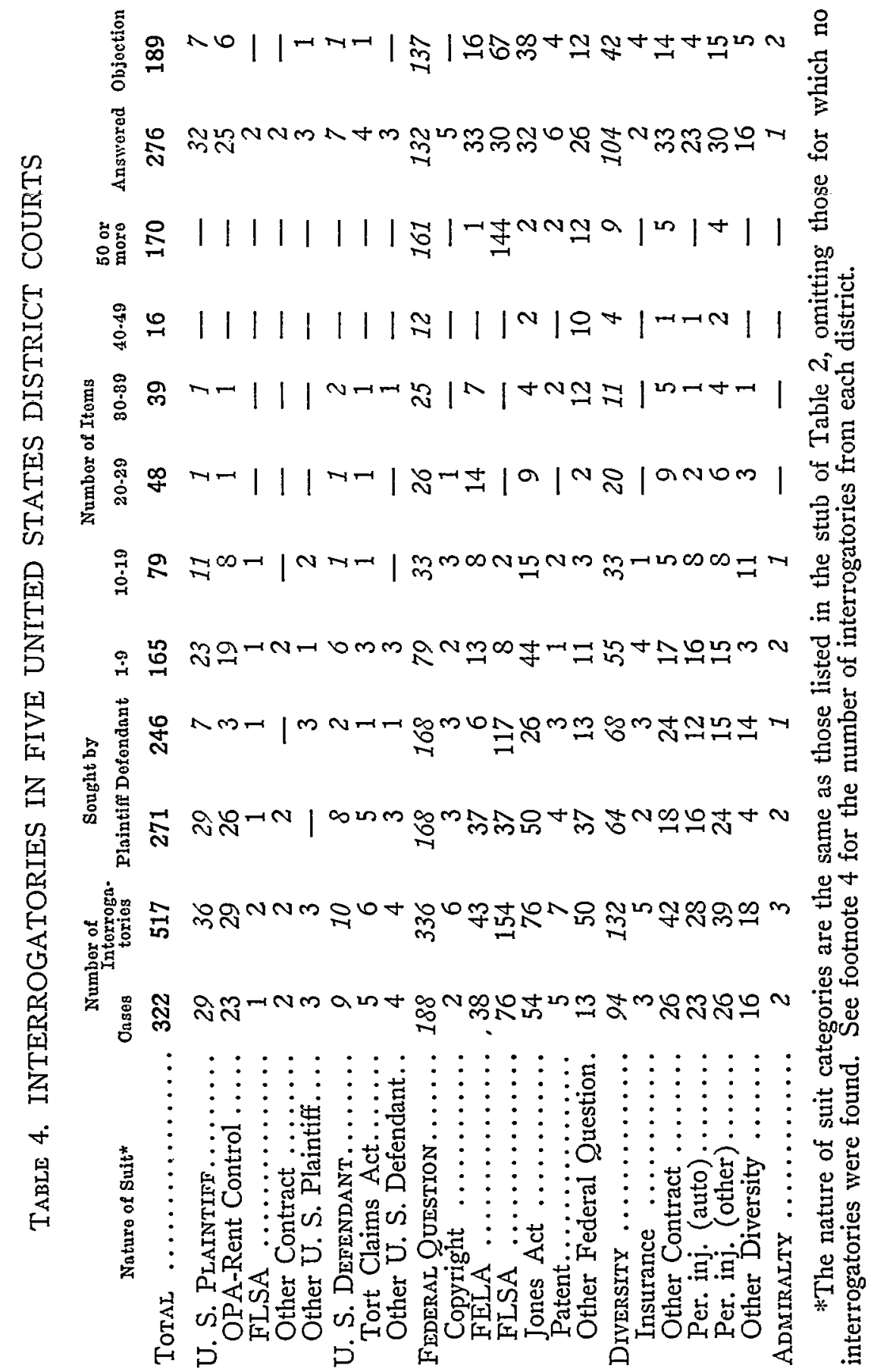




\section{Motions for Production or Inspection}

Motions for production or inspection, numerically of little importance, appeared in only $4 \%$ of the cases filed. But much material is voluntarily furnished by attorneys, particularly in Jones Act and Federal Employers Liability Act suits where a few plaintiff's counsel are constantly dealing with a few defendant's counsel. In addition similar materials may often be obtained more easily by subpoena duces tecum under Rule 45 (d)(1), because it is not necessary to go to the judge and show good cause. Furthermore, in Philadelphia prior to the Alltmont case copies of statements could be obtained by interrogatories.

These motions were made overwhelmingly by plaintiffs in almost every category of suit. See Table 5 page 1147. The materials sought were almost always papers of some sort: record books, documents, files, photographs, etc. Remaining motions sought inspection of such property as models, machines, samples of material, real estate, or a steam ship when next in port. In some instances a motion may verge upon either an interrogatory if it calls for the production of a paper giving certain information and no existing paper gives that information, or upon a deposition if it calls upon the other side to produce an employee for oral examination. The plaintiff in a Jones Act case may ask for all statements of the plaintiff or witnesses, log entries, medical reports, Coast Guard reports, statements of the master, and all other reports in the regular course of business. In a civil rights suit to correct unequal facilities in segregated Virginia schools the plaintiffs sought enrollment and attendance records, accounts of tuition paid for attendance outside the country, school census by race and age, records of teacher qualifications and salaries, courses offered, capital investment in school facilities, costs of operation, and the right to inspect school premises. Three fifths of the motions were granted; in the remainder the motion was denied, abandoned, or acquiesced in by the other party.

\section{Motions for Physical Examination}

Motions for physical examinations rarely appear on the dockets, apparently because when the right is clear, as it usually is, voluntary arrangements are made for examinations. Such arrangements have been encouraged by decisions that voluntary submission does not waive the right to copies of medical reports. ${ }^{16}$ In New York defendants often accompany their answers with a "notice" to examine the plaintiff both orally and physically. Some maritime defendants make a general practice of taking physical examinations of living plaintiffs. In practice, motions are confined to personal injury and particularly to Diversity personal injury cases. The defendants in Federal Question per-

16. Kelleher v. Cohoes Trucking Co. Inc., 25 F. Supp. 965 (S.D. N.Y. 1938): Rutherford v. Alben, 1 F.R.D. 277 (S.D. W.Va. 1940); Lipshitz v. Bleyhl, 5 F.R.D. 225 (E.D. N.Y. 1946). 
"영

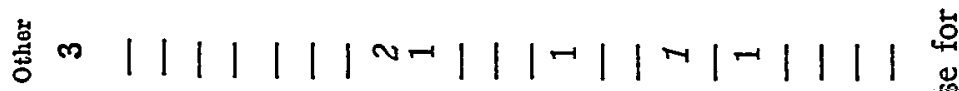
范

Z 焉 $60^{\circ}$ .

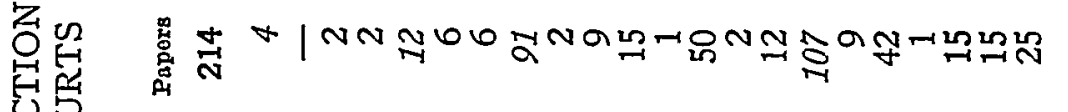
됭 宛 营兒

s)

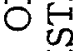

号苚

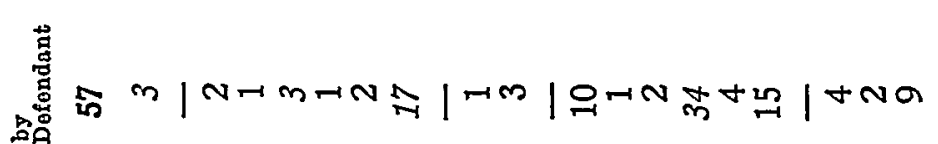
荧

吸

乌ํㅗㅂ

Оิ

of

娓点

니

营昆

要

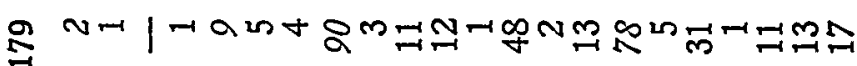

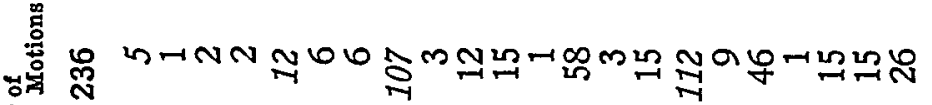
营.

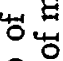
药蓠 $\stackrel{\mathscr{E}}{\underline{\Xi}}$ . 可广 $\stackrel{2}{0}$ 号 車岁 ชู 兽

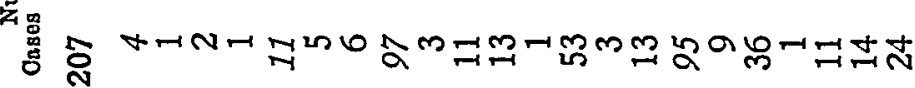


sonal injury cases under the Federal Employers Liability Act and Jones Act are employers and often have other means of getting medical examinations of plaintiffs. In one case a plaintiff unsuccessfully sought the physical examination of a crane operator whose negligence was alleged to have caused his injury. In almost every other instance the defendant took the medical examination of the plaintiff.

\section{Requests for Admissions}

Requests for admissions are little used and appeared in only $3 \%$ of the cases. They were used most often in government OPA-Rent Control suits $(20 \%)$ and to a lesser extent in government contract suits (6\%), copyright $(7 \%)$, and Diversity insurance cases $(7 \%)$. One limitation on their use may be that the words "a written request" in Rule 36 are understood to limit a party without the court's permission, to one request. But some requests often amounted to a step by step development of a plaintiff's case. In OPA cases, for example, the government sought admissions concerning registration statements, rent orders, the landlord, his agents, tenants, rents paid, and the absence of refunds or suits for refunds. Upon the answers to these requests or upon the failure to answer, the government frequently moved for summary judgment. In a Jones Act suit the plaintiff may seek admissions as to his employment, the ship's location, his injury, the treatment, his efforts to work, and the maintenance and cure received.

Requests for admissions were almost always sought by plaintiffs. See Table 6 page 1149. The only exception was in Diversity personal injury motor vehicle cases. The number of items in requests was quite small-the median was only about 13 . Only 23 requests covered 50 or more items, and 19 of these were in government OPA cases where the number of tenancies was large. Two-thirds of the admissions were answered, and the remainder might be deemed admitted by virtue of Rule 36 . Objections or other court activity appeared in fewer than one-quarter of the requests. But the over-all proportion of objection was probably smaller, for while all objected-to requests were likely to appear in the files, it was unlikely that all those not objected to would appear.

\section{ConCLUSION}

\section{Are the Criticisms of Discovery Valid?}

The best testimonial to the worth of discovery is the extent of its voluntary use. Some form of discovery appears to be used in virtually all seriously contested tort cases and in most of the many categories of business cases. Moreover, most lawyers like liberal discovery: those representing plaintiffs in tort cases were heartily enthusiastic; some of those representing defendants were equally favorable, although some were lukewarm or doubtful; and a few representing defendants in business litigation had criticisms. Lawyers critical of discovery said that they were constantly going through their files to 


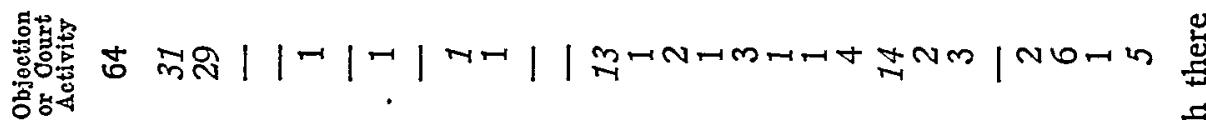

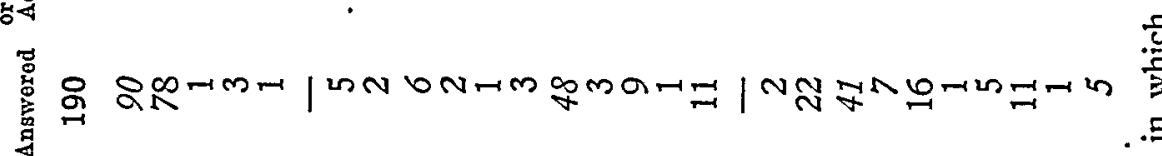

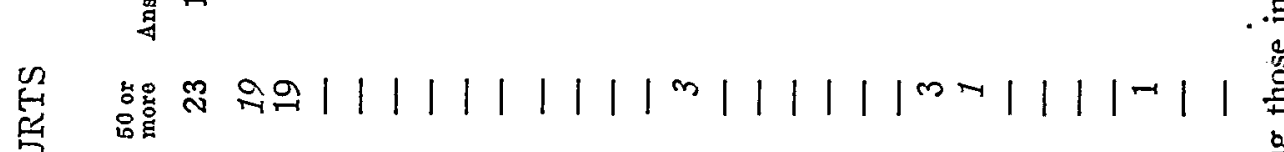

8

$\underset{U}{H}$

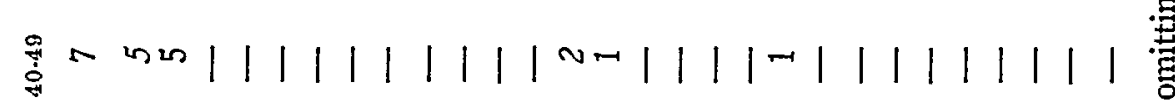

叠离

$\stackrel{n}{a}$

o

(I)

兽 总

苛太 ma

范:

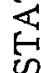

舀

되

空

学

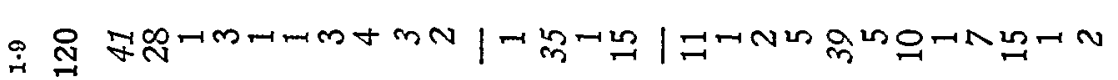

5

年

若 迹.

递

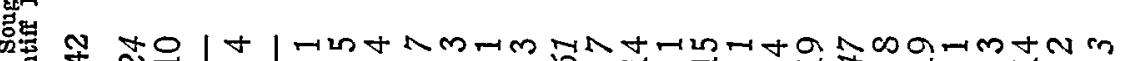

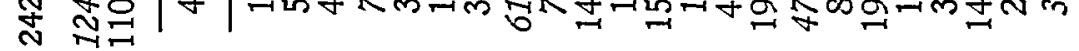

(1)

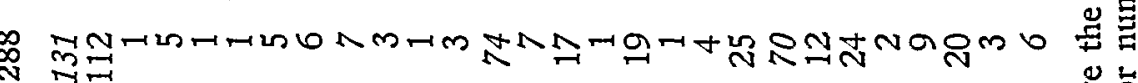
客帘

券总

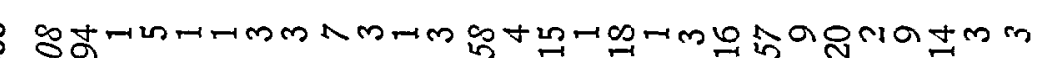

总

\%

岁范

6

岳

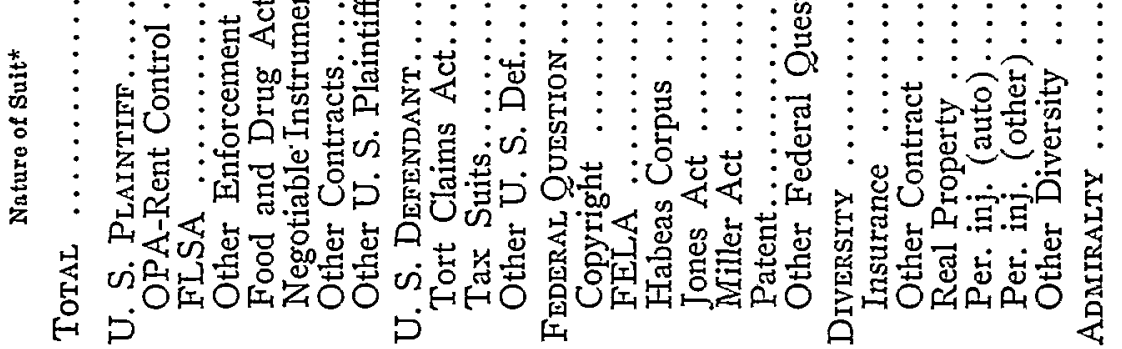

焉若

言觉员

岁。

흠 
prepare for discovery proceedings and that the resulting expense in many small cases was out of proportion to the value. Others said that corporate defendants could give but not get discovery information because their clients could not afford and would not be allowed to practice the kind of evasions that were almost regarded as praiseworthy in plaintiffs.

The cost of discovery is not exorbitant. In the ordinary tort case full investigation by deposition might result in taking the testimony of four or five witnesses, probably all within the district, over a period of four or five hours for a total of approximately 150 pages. This would cost the examiner perhaps $\$ 100$ for the reporter and transcription and, allowing $\$ 50$ per deposition for attorney fees, another $\$ 200$ for his lawyer. In these personal injury cases interrogatories, requests for admissions, and motions to produce should cause only negligible expense. In the ordinary business case depositions might be somewhat longer because of the number of transactions involved. Production of files might also cause some expense and inconvenience. In the gigantic business case, expense would be much greater. Motions to produce call for tons of files; interrogatories require extensive research; and depositions run to thousands of pages. But these cases are few and atypical, and the amount of discovery in them is probably not out of proportion to the sums of money at stake. If 100 to 150 pages of depositions are reasonable in a tort case worth $\$ 20,000$, then 100,000 to 150,000 pages would not be out of proportion in a case worth $\$ 20,000,000$. Discovery expense in giant cases can probably only be minimized by the intervention of the judge, at an early stage, in order to organize the discovery activities of both parties, with a view to bringing out information economically. ${ }^{17}$ Judges are aware of the cost of discovery and try to minimize expense. ${ }^{18}$

Some criticism arises from the fact that the party seeking discovery is not responsible for the trouble and expense of getting the information requested. In some instances the information sought is difficult and expensive to obtain and of slight relevance; and yet, since the attorney demanding the information does not bear the expense of getting it, that expense does not temper his demands. The result is a certain amount of maneuvering to put the burden of preparing the case upon the other side, as is perhaps illustrated in the Fair Labor Standards Act cases already discussed. ${ }^{19}$

17. Whitney, supra note 3. A committtee of the Judicial Conference under the chairmanship of Judge Prettyman has been studying the trial problems of big cases.

18. See cases in note 9 supra and United States v. National City Bank, 1 F.R.D. 367 (S.D. N.Y. 1940); Sullivan v. Southern Pacific Co., 7 F.R.D. 206 (S.D. N.Y. 1947); Butts v. Southern Pacific Co., 7 F.R.D. 194 (S.D. N.Y. 1947) ; Isbrandsten v. Moller, 7 F.R.D. 188 (S.D. N.Y. 1947); Frito Co. of Cleveland v. Morton Salt Co., 10 F.R.D. 384 (N.D. Ohio 1950); Savannah Theatre Co. v. Lucas \& Jenkins, 10 F.R.D. 461 (N.D. Ga. 1943).

19. E.g. O'Malley v. Chrysler Corp., 160 F.2d 35 (7th Cir. 1947); Brown v. Dunbar \& Sullivan Dredging Co., 8 F.R.D. 107, 105 (W.D. N.Y. 1948). 
Apparently, discovery is not used to pry into private affairs. Occasionally it is said that a suit is a mere pretense to take advantage of discovery, and that parallel suits are brought in state and federal courts to take advantage of more liberal federal discovery. No such instances were found, and the attorneys mentioned "prying" more as a theoretical possibility than as an actuality. Persons from whom discovery is sought fear that it will bring out illegal activities, trade secrets, or simply embarrassing facts. Unfortunately when a person becomes involved in litigation much material that he would ordinarily like to keep private becomes of judicial concern, and the person subject to discovery is likely to value his desire for privacy higher than he values the judicial interest in full disclosure. Judges endeavor to limit discovery to the needs of the lawsuit ${ }^{20}$ and have declined to permit use of federal discovery for ulterior purposes. ${ }^{21}$ But the probability that litigation will bring out relevant material that a party would prefer to keep hidden certainly influences decisions to sue or to settle.

Dilatoriness of discovery is scarcely a problem in metropolitan districts where a judge is always available to decide discovery motions, ${ }^{22}$ and where getting to trial takes months or years because of crowded calendars. But it is sometimes a problem in courts without a resident judge, for an objection to discovery with a demand for oral argument may delay proceedings until the next term and may postpone trial for one or more terms. Nevertheless, discovery motions seem to be taking more judge time than they should. Of 1,110 matters on the motion calendars in New York during January and February $1951,40 \%$ dealt with some type of discovery; $16 \%$ dealt with interrogatories, $13 \%$ with depositions, $10 \%$ with motions to produce, and $1 \%$ with admissions. Other districts where the data could be obtained confirmed this story. In Philadelphia, $28 \%$ of the matters on the argument lists during the calendar year 1950 dealt with discovery and $20 \%$ dealt with interrogatories. In Maryland, of the matters on the motion calendars for July 1950 through April 1951, 21\% dealt with some type of discovery, $10 \%$ dealt with motions to produce, $9 \%$ with interrogatories, and $1.5 \%$ with depositions. Even if the time required for disposition of discovery motions is less than that required for other types of motions, the number of motions dealing with discovery seems excessive.

20. Cooney v. Guild Co., 1 F.R.D. 246 (S.D. N.Y. 1940); Smith, Kline \& French Laboratories v. Lannett Co., 3 F.R.D. 51 (E.D. Pa. 1943); Swoboda v. Carton Finishers, 6 F.R.D. 600 (N.D. Ill. 1946) ; Remington Rand Inc. v. Control Instrument Co., 7 F.R.D. 18 (E.D. N.Y. 1947) ; Caplin v. United Feature Syndicate, Inc., S F.R.D. 424 (S.D. N.Y. 1948) ; Garrett v. Faust, 8 F.R.D. 556 (E.D. Pa. 1949); Hen-Ray Food Markets, Inc. v. Great American Indemnity Co., 8 F.R.D. 549 (E.D. Pa. 1949); Cresmer v. United States, 9 F.R.D. 203 (E.D. N.Y. 1949); G. \& P. Amusement Co. v. Regent Theater Co., 9 F.R.D. 721 (N.D. Ohio 1949); cf. Ferguson v. Ford Motor Co., 8 F.R.D. 414 (S.D. N.Y. 1948).

21. See MOORE's Federal PRActice $\$ 26.14$ (1950).

22. In New York many depositions are taken in the Federal court house so that a judge can be reached quickly. Kirshner v. Palmer, 7 F.R.D. 252 (S.D. N.Y. 1945). 
For cases in Maryland and Chicago a comparison was made between those using and not using discovery as to all cases disposed of both before and after trial, with regard to the time elapsing from filing to termination. The results show that the disposition of cases with discovery takes longer than do those without discovery. The connection may not be a causal one, for discovery is probably most frequently used in stubbornly contested cases. But discovery activity necessarily takes some time, and the advantages of discovery undoubtedly lead many plaintiffs to undertake much of their case investigation after filing suit rather than before, so that some delays resulting from discovery would be expected.

Lawyers agreed that discovery devices are used in some cases to harass the other side into a settlement- "to create an atmosphere for settlement" as one phrased it-but they were unable to estimate the extent of this abuse. Harassment may take the form of long time-wasting depositions of important officers, ${ }^{23}$ of multiplying expense by hundreds of distant depositions, of interrogatories calling for thousands of information items, of demands for tons of business files, or of prying into irrelevant and embarrassing private matters. Occasionally applications to take, within the district, the depositions of non-resident parties seem to be for the purpose of harassment. ${ }^{24}$ One attorney stated that the possibility of prolonged discovery before trial made him hesitate to accept retainers from persons with limited means because, although he could reasonably estimate the time required for other aspects of the case, he could not forecast the time required for discovery.

Except for the FLSA cases already mentioned, this study revealed no general harassment. The potential field of this abuse can be delimited. Lawyers agreed that harassment does not occur in tort cases where the attorneys are very busy and the type of information that can be sought is relatively limited. Deliberate harassment is likely to occur, if at all, in business litigation-private anti-trust cases, stockholders suits, and perhaps in some copyright, patent, trade mark, and contract cases-where the range of potentially relevant material can be tremendous. ${ }^{25}$ This study disclosed longer depositions and more numerous interrogatories in business than in tort cases. This abuse is likely to occur in cases constituting at the most about one-fifth of the total case filings in which about one-quarter of the total discovery is done. It has also been suggested that this abuse is probably limited to multi-judge districts, for lawyers do not care to go to trial before a judge who has ruled on their discovery abuse.

23. E.g. Heiner v. North American Coal Corp., 3 F.R.D. 64 (W.D. Pa. 1942).

24. Isbrandsten v. Moller, 7 F.R.D. 188 (S.D. N.Y. 1947); Butts v. Southern Pacific Co., 7 F.R.D. 194 (S.D. N.Y. 1947); Sullivan v. Southern Pacific Co., 7 F.R.D. 206 (S.D. N.Y. 1947) ; Anthony v. RKO Radio Pictures, 8 F.R.D. 422 (S.D. N.Y. 1948); Solomon v. Teitelbaum, 9 F.R.D. 515 (E.D. N.Y. 1949).

25. For an excellent description of abuse in New York commercial cases see Comment, Tactical Use and Abuse of Depositions under the Federal Rules, 59 YaLE L.J. 117 (1949). 
Lawyers could not estimate the extent of abuse in these cases and hesitated to suggest remedies that would interfere with the advantages of full disclosure in discovery. They pointed out that deliberate harassment is self-limiting in that it is expensive and time consuming for the harassing side and is likely to make an unfavorable impression upon the judge and jury. One article suggests that court approval be required for depositions of more than five days duration. ${ }^{26}$ Such a limit would not reach harassment by taking scores of short depositions. Any limitation ought to apply to the whole program of depositions and discovery. Ultimately curtailment of abuse must depend upon the alertness of judges in recognizing harassment and their firmness in enforcing the responsibilities of lawyers as officers of the court.

Lawyers do race for priority in discovery, apparently more in New York than in other districts. The defendant's initial advantage is one of priority. It is perhaps offset to some extent by the fact that the plaintiff with ample time to investigate the facts and law before filing suit can make his own initial use of discovery extremely effective by trapping the defendant with carefully loaded questions. One attorney suggested that priority be given to the party with the burden of proof on most of the issues. The practice of giving priority to the party first initiating discovery is not expressly required by the rules and even as stated in opinions is subject to variation for "special circumstances." 27 Perhaps as judges become more aware of the possibility of discovery abuse, "exceptional circumstances" may be more frequently relied on to justify deviation from the rule of first-to-seek firstto-discover.

Lawyers generally agreed that where abuse was occurring relief could not be obtained from judges, either because judges could not learn enough about the case at the pre-trial stage to rule effectively or because of trouble, expense, and delay in obtaining relief. Although published court opinions indicate that judges are discriminating in ordering discovery, many lawyers believe that judges will generally order all the discovery asked. Nevertheless, the substantial number of discovery motions on the calendars indicates that most lawyers have apparently not given up hope of court relief.

Some lawyers also felt that rulings on discovery were not uniform and that inconsistency prevented development of voluntary practices for the exchange of information. Whether this belief is justified could not be determined. The crucial discovery rules turning around "relevant to the subject matter," the qualified privilege of counsel under Hickman v. Taylor,

26. See Comment supra note 25 , at 133 .

27. Moore's FEderal PRACTice $\$ 26.13$ (1950); Hillside Amusement Co. v. Warner Bros. Pictures, Inc., 2 F.R.D. 275 (S.D. N.Y. 1942) ; Ginsberg v. Railway Express Agency, Inc., 6 F.R.D. 371 (S.D. N.Y. 1945); Forstmann Woolen Co. v. Manufacturers Retail Men's Stores, Inc., 6 F.R.D. 224 (S.D. N.Y. 1946); Mutual Finance Corp. v. Sobol, 7 F.R.D. 111 (S.D. N.Y. 1946) ; Hare v. Southern Pacific Co., 9 F.R.D. 307 (N.D. N.Y. 1949) ; Edwin H. Morris \& Co. v. Warner Bros. Pictures, Inc., 10 F.R.D. 236 (S.D. N.Y. 1950). 
and "good cause" are necessarily and deliberately indefinite. The complaining lawyers were perhaps insensitive to distinctions between cases and obsessed with a desire for certainty at the expense of flexibility in decision.

Despite the claim that trial by deposition is making a comeback, trials are not being heard largely on depositions or other discovery material. Data already presented from New York, Maryland, and Philadelphia disclosed the use of depositions in only about one-third of the trials. Use of interrogatories and admissions was rare. ${ }^{28}$ Although many of the exhibits may have been obtained by motion to produce, the number so obtained could not be determined, and their use in evidence is certainly not objectionable. In none of the trials examined did depositions or other discovery material constitute the only evidence. Under the limitations of Rule 26(d) (3) depositions can only be used in circumstances in which it is unlikely that the witness would be available, i.e., the choice is between deposition evidence and none at all.

Facilitation of perjury has been a bogey man of discovery for over a hundred years. No evidence can be produced conclusively to prove or disprove it, ${ }^{29}$ and the consensus among lawyers is to reject it. ${ }^{30}$ This investigation disclosed the variety of ways in which lawyers use discovery to thwart perjury. Defendants customarily take a deposition and make a physical examination of the plaintiff immediately after suit is filed to freeze his account both of the accident and of his injuries before he has learned too much about what facts will support his recovery. The answers to interrogatories and admissions, documents obtained by motions to produce, and testimony on deposition are checked against one another and against testimony at the trial to outwit the perjurer. It has recently been suggested that perjury can be thwarted by more discovery or by rearrangement of discovery so as to allow time to take depositions before producing statements, to file documents simultaneously, and to give priority to the party lacking first hand knowledge of the facts. ${ }^{31}$

The liveliest field of discovery law has recently been that concerned with disclosure of the other side's trial preparations-the problem of Hickman $v$. Taylor. This investigation disclosed that in tort cases lawyers very often seek discovery of materials that were obtained in preparation for trial or for possible litigation. In New York, interrogatories in six of 12 FELA cases and two of 20 Jones Act cases sought such information, and motions to produe in 30 of 36 Jones Act cases and nine of 13 personal injury cases sought to obtain statements, reports, photographs, etc. probably prepared

28. In addition to the 133 depositions only eight answers to interrogatories and one admission were introduced in the 150 trials in New York from July 1950 through December 1950 .

29. Hoffman v. Palmer, 129 F.2d 976, 997 (2d. Cir. 1942).

30. Ragland, supra note 5 , at 124 .

31. Yudkin, supra note 3 , at 295 . 
in anticipation of litigation. Such discovery is unpopular with defendants' counsel who fear perjury and dislike the use of their preparations by the other side. They particularly dislike being obliged to produce statements of witnesses who are known and available on the plea that plaintiff lacks means to interview them or take their depositions, because plaintiff's counsel is usually financing the case and can interview or take depositions if he thinks it really worth while. But even such understandable criticism cannot outweigh the desirability, in the administration of justice, of having all possible information in the hands of both parties, unless such disclosure results in deterioration of investigation and trial preparations. There were only hints of such results: one suggestion that certain materials were no longer kept in the attorney's file because they might be producible; another indication that the formal reports of ship officers no longer told the whole truth but were supplemented by letters or conversations. Wholesale disclosure of trial preparations and of accident reports may sometime either interfere with adequate preparation or reduce the effectiveness of accident prevention investigation. But disclosure is not so unrestricted, and there is no evidence that careful trial preparation and investigation are not still worthwhile.

\section{Is Discovery Bearing Out the Hopes of Its Proponents?}

Court opinions show that discovery is being relied upon to fill out the details of pleadings. This study has described examples of such use, particularly of the interrogatory, to gain information on contentions and to push aside frivolous allegations.

Discovery does not appear to have been successful in speeding the disposition of cases, for instead the courts seem to have taken over a larger share of the burden of investigation. A comparison between cases with and without discovery in Chicago and Maryland disclosed that discovery is associated both with the cases which take longer to dispose of and with cases which more often go to trial. Moreover, the large number of objections to discovery on the motion calendars indicates that, to some extent, motion maneuvers formerly directed toward pleadings have been transferred to discovery. Yet, especially in big cases, the opportunity to get at all the evidence well before trial does facilitate the organization of trial evidence and should shorten trials.

Finally, discovery does appear to have fulfilled expectations in making information and evidence readily available to all parties. It is popular and employed extensively. The use of discovery devices has given effect to substantive rights in both tort and business litigations. Without liberal discovery thousands of parties would each year be unable to strbstantiate their legal rights. 


\section{THE YALE LAW JOURNAL}

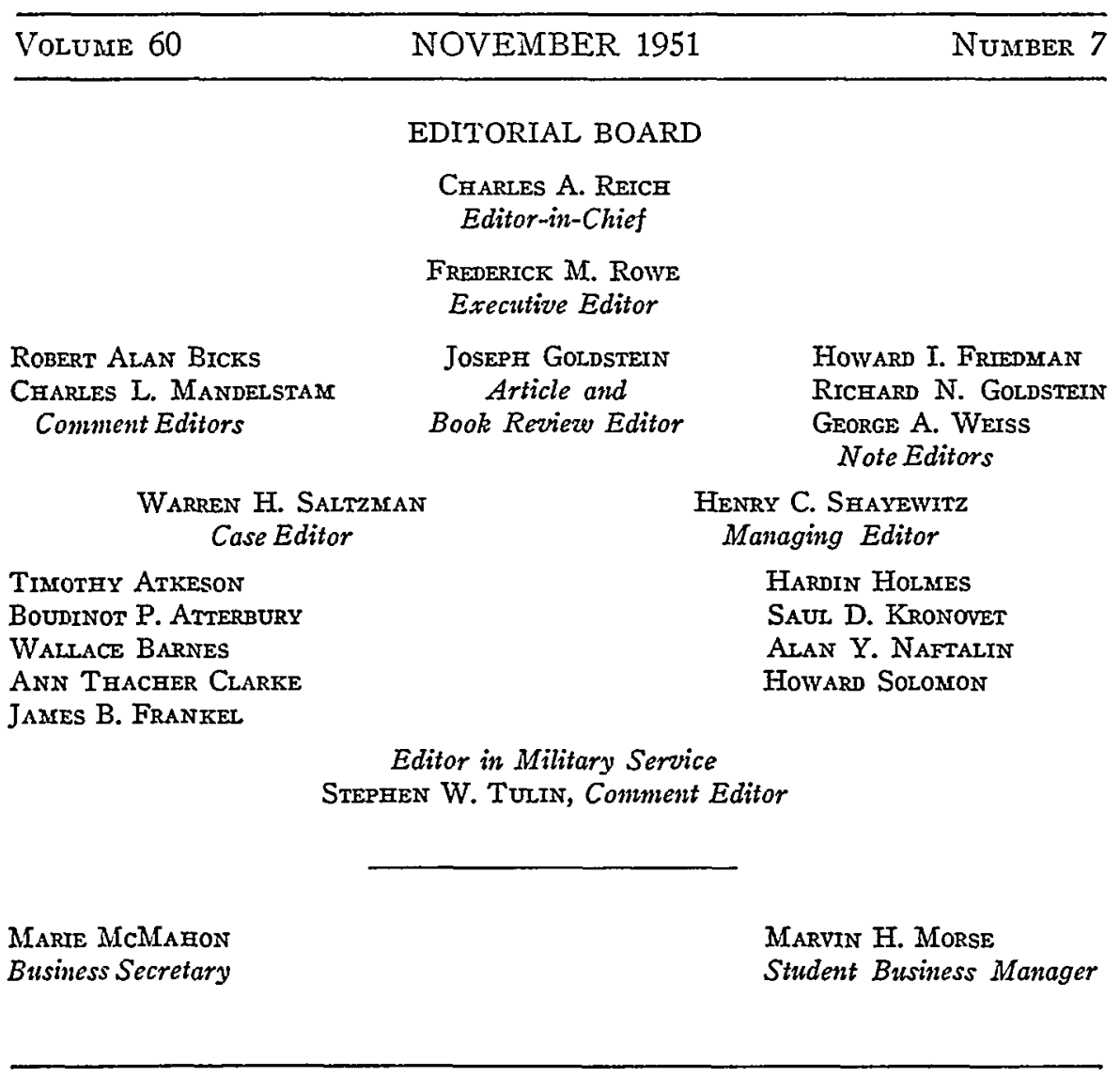

CONTRIBUTORS TO THIS ISSUE

Chardes E. Clark. B.A. 1911, LI.B. 1913, Yale University. Dean of Yale Law School, 1929-1939. Judge, United States Court of Appeals for the Second Circuit.

Kenneth S. Carlston. B.B.A. 1926, University of Washington; M.A. 1928, American University, Washington, D. C.; LL.B. 1933, Yale University. Professor of Law, University of Illinois.

Ricenard C. Donnelly. Ph.B. 1936, Washburn College; LL.B. 1938, Washburn University; J.S.D. 1949, Yale Law School. Associate Professor of Law, Yale Law School.

Wilrialr H. Speck. A.B. 1940, J.D. 1942, University of Chicago. Member of the Illinois Bar; Attorney, Division of Procedural Studies and Statistics, Administrative Office of the United States Courts. 